\title{
Korelasi Jumlah CD4 Pasien yang Diberi Isoniazid dengan Ko-infeksi TB pada Pasien HIV/AIDS
}

\author{
Zulfian $^{1}$, Neno Fitriyani Hasbie ${ }^{2}$, Arif Effendi ${ }^{3}$, Niken Ayu Farida Salim ${ }^{4 *}$ \\ ${ }^{1)}$ Departemen Patologi Klinik, Fakultas Kedokteran, Universitas Malahayati, zulfianbahri@gmail.com \\ ${ }^{2}$ Departemen IKM, Fakultas Kedokteran, Universitas Malahayati, nenohasbie@yahoo.com \\ ${ }^{3}$ Departemen Dermatovenerologi, RSUD Dr. H. Abdul Moeloek Lampung, arif.effendi62@gmail.com \\ ${ }^{4)}$ Fakultas Kedokteran, Universitas Malahayati,faridanikenayu@gmail.com
}

\begin{abstract}
ABSTRAK
Interaksi antara TB dan infeksi HIV merupakan interaksi yang komplek. Pada individu yang terinfeksi HIV keadaan ini akan menyebabkan penurunan sistem imun dan meningkatkan kerentanan akan kejadian TB. HIV menyebabkan reaktivasi, reinfeksi dan progesivitas infeksi TB laten menjadi TB aktif. Hal ini juga menyebabkan perbedaan presentasi klinis TB pada pasien HIV, komplikasi dan respons terhadap pengobatan anti TB dibandingkan pada pasien HIV negatiff. Tujuan dari penelitian ini adalah mengetahui Korelasi Jumlah CD4 Pada Pasien HIVIAIDS di RSUD Dr.H. Abdul Moeloek Provinsi Lampung Tahun 2018. Metode: Pendekatan cross-sectional, dimana beberapa variabel yang diuji pada objek penelitian ini data didapatkan dari rekam medik. Analisis data yang digunakan adalah uji statistik Mann-Whitney. Hasil penelitian menunjukkan Jumlah sampel 160 rekam medik pasien dilihat bahwa nilai Asymp. Sig. (2-tailed) adalah 0,000. Setengah dari nilai signifikansi ini 1/2(0,000) <0,05. Maka dapat disimpulkan bahwa menolak HO dan Ha diterima yang mengandung pengertian bahwa ada perbedaan yang signifikan jumlah CD4 pada pasien yang diberi isoniazid sebagai pencegahan TB dengan pasien Ko - Infeksi TB. Dengan kekuatan korelasi artinya bahwa adanya hubungan jumlah CD4 pada pasien yang diberin isoniazid sebagai pencegahan TB dan ko-infeksi TB. Kesimpulan: Ada hubungan bermakna antara jumlah CD4 pada pasien yang diberin isoniazid sebagai pencegahan TB dan ko-infeksi TB pada pasien HIV/AIDS di RSUD Dr.H. Abdul Moeloek Provinsi Lampung Tahun 2018
\end{abstract}

Kata kunci: Isoniazid, Ko-infeksi TB, HIV/AIDS

\begin{abstract}
The interaction between TB and HIV infection is complex. In HIV-infected individuals, this situation will decrease the immune system and increase vulnerability to $T B$ incidence. HIV causes reactivation, reinfection, and progression of latent TB infection to active tuberculosis. It also led to differences in the clinical presentation of TB in HIV patients, complications, and response to anti-TB treatment than in HIV negative patients. The purpose of this study To Know Correlation CD4 counts in patients with HIV / AIDS in hospitals Dr.H. Abdul Moeloek Lampung Province 2018. Research methods: cross-sectional approach, in which several variables tested in this research object data got from the medical record. Analysis of the data used is the Mann-Whitney statistical test. Research The total sample of 160 medical records of patients seen that the Asymp. Sig. (2-tailed) is 0,000. Half of this significance value $1 / 2(0.000)$ is $<0.05$. It can be concluded that reject HO and Ha accepted, which implies a significant difference in CD4 cell counts in patients given isoniazid as TB prevention with patients TB co-infection. With all forces, correlation means that their relationship CD4 cell counts in patients given isoniazid to prevent TB and TB co-infection. There is a significant relationship between CD4 cell count in patients who given isoniazid for the prevention of TB and TB co-infection in HIV / AIDS patients in hospitals Dr.H. Abdul Moeloek Lampung Province 2018.
\end{abstract}

Keywords: Isoniazid, Co-infection of TB, HIV/AIDS

*Korespondensi Author: Niken Ayu Farida Salim, Program Studi Kedokteran Fakultas Kedokteran Universitas Malahayati,faridanikenayu@gmail.com,08877808424

\section{PENDAHULUAN}

Human Immunodeficiency Virus (HIV) merupakan virus yang menyerang atau menginfeksi limfosit $\mathrm{T}$ CD4+ sehingga menyebabkan turunnya kekebalan tubuh manusia. Acquired Immune Deficiency Syndrome (AIDS) adalah sekumpulan gejala penyakit yang timbul karena turunnya kekebalan tubuh yang disebabkan infeksi oleh HIV. Akibat nya kekebalan tubuh maka orang tersebut sangat 
mudah terkena berbagai penyakit infeksi (infeksi oportunistik) yang sering berakibat fatal. Pengidap HIV memerlukan pengobatan Antiretroviral (ARV untuk menurunkan jumlah virus HIV di dalam tubuh agar tidak masuk ke stadium AIDS, sedangkan pengidap AIDS memerlukan ARV untuk mencegah terjadinya infeksi oportunistik dengan berbagai komplikasinya. ${ }^{1}$

Menurut laporan terbaru, United Nations on HIV/AIDS (UNAIDS) tahun 2018, Secara keseluruhan pertumbuhan dari epidemik AIDS telah stabil jumlah tahunan kasus infeksi baru HIV dan AIDS terkait dengan mortalitas telah berkurang. Di dunia estimasi jumlah kasus HIV adalah 2.200.000 Jumlah kasus infeksi baru telah menurun hingga $42 \%$ di Sub Sahara Afrika. Penurunan juga berlanjut di Asia dan Pasifik (39\%) Eropa Barat, Eropa Tengah dan Amerika Utara (36\%), dan Karibia (23\%). ${ }^{2}$

Di Indonesia pada tahun 2017 terdapat jumlah kasus baru HIV sebanyak 48,300 dan mengalami penurunan $\pm 3,5 \%$ di tahun 2018 menjadi 46,659. Dan untuk kasus AIDS tahun 2017 jumlah kasus baru yaitu 10,488 dan berkurang di tahun 2018 menjadi 10,190. Di provinsi Lampung sendiri dilaporkan kasus baru HIV yaitu 524 dan kasus AIDS $143 .{ }^{1}$

Tuberkulosis atau TB merupakan masalah kesehatan masyarakat yang menjadi tantangan global. Secara global pada tahun 2016 terdapat 10,4 juta kasus insiden TBC (CI 8,8 juta-12 juta) yang setara dengan 120 kasus per 100.000 penduduk. Sebagian besar estimasi insiden TBC pada tahun 2016 terjadi di Kawasan Asia Tenggara (45\%) Lima negara dengan insiden kasus tertinggi yaitu India, Indonesia, China, Philipina, dana Pakistan. Jumlah kasus baru TB di Indonesia sebanyak 420,994 kasus pada tahun 2017 (data per $17 \mathrm{Mei}$ 2018). ${ }^{3}$

Di Asia Tenggara, sekitar 74.000 orang meninggal karena koinfeksi HIV-TB dengan 12 kasus per 100.000 penduduk pada tahun 2015, dan Indonesia merupakan yang tercepat dengan rata-rata 63.000 kasus TB dengan HIV positif per tahun dengan tingkat mortalitas sebanyak 22.000 kasus per tahun. ${ }^{3}$ Interaksi antara TB dan infeksi HIV merupakan interaksi yang komplek. Pada individu yang terinfeksi HIV keadaan ini akan menyebabkan penurunan sistem imun dan meningkatkan kerentanan akan kejadian TB. HIV menyebabkan reaktivasi, reinfeksi dan progesivitas infeksi TB laten menjadi TB aktif. Hal ini juga menyebabkan perbedaan presentasi klinis TB pada pasien HIV, komplikasi dan respons terhadap pengobatan anti TB dibandingkan pada pasien HIV negatif. ${ }^{4}$

Pada tahun 2011 WHO mengeluarkan Guadlines for Intensified TB case-Finding and IPT for PLHIV in Resource Constrained Settings. Berdasarkan hasil 12 uji klinis acak The Cochrane review of preventive therapy dilaporkan orang dengan diagnosis HIV yang belum pasti sakit TB pemberian obat profilaksis TB dapat menurunkan risiko keseluruhan terjadinya TB sebesar 33\% dan bagi mereka dengan Tuberkulin Skin Testing (TST) positif risiko akan menurun hingga 64\%. Pada penelitian Grand dkk, diketahui bahwa pemberian profilaksis INH pada ODHA menurunkan insidens TB sebesar $38 \%$ pada orang dengan dan tanpa riwayat TB sebelum pemberian IPT. ${ }^{5}$ Berdasarkan penelitian tersebut pemberian profilaksis INH dapat menurunkan angka kejadian sakit TB pada pasien HIV namun sampai saat ini pemberian profilaksis INH belum menjadi kebijakan pengendalian TB di Indonesia. Pada penelitian kali ini peneliti membandingkan dan melihat hubungan antara pemberian INH pada pasien HIV sebagai pencegahan TB dengan pasien HIV TB dilihat dari kadar CD4.

\section{METODOLOGI}

Jenis penelitian yang digunakan pada penelitian ini kuantitatif desain analitik dengan pendekatan cross-sectional melalui rekam medik pasien HIV/AIDS. Penelitian ini dilakukan di poli VCT RSUD Dr. H. Abdul Moeloek Provinsi Lampung, dan waktu penelitiannya adalah bulan Februari 2020. Sampel dalam penelitian ini adalah data rekam medik pasien HIV/AIDS yang sesuai dengan kriteria inklusi dan eksklusi yang berjumlah 160 rekam medik dengan teknik pengambilan sampel pada 
penelitian ini adalah purposive sampling. Data dianalisis dengan menggunakan Uji MannWhitney. Data yang dipergunakan dalam penelitian ini diantaranya jenis kelamin penderita, usia penderita, pendidikan, transmisi, dan rerata CD4.

\section{HASIL DAN PEMBAHASAN}

Data dalam penelitian ini didapat dari rekam medik pasien yang tercatat di Poli VCT Kanca Sehati RSUD Dr. H. Abdul Moeloek Provinsi Lampung. Pada penelitian ini didapatkan responden penelitian sebanyak 160 sampel. Penelitian ini diolah dengan menggunakan analisis univariat untuk menjabarkan tabel distribusi frekuensi sampel penelitian, kemudian dilanjutkan dengan analisis bivariat yang dilakukan untuk mengetahui hubungan variabel bebas dan variabel terikat.

Berikut ini data hasil penelitian yang ditampilkan dalam bentuk tabel. Terdiri atas beberapa distribusi data yang menggambarkan karakteristik sampel menurut jenis kelamin, usia, pendidikan, transmisi, kelompok CD4, rerata CD4. Dan disertai hasil uji korelasi dan hubungan variabel bebas dan variabel terikat.

Tabel 1. Karakteristik Subjek Penelitian

\begin{tabular}{|c|c|c|c|}
\hline \multicolumn{2}{|c|}{ Karakteristik } & Frekuensi & Presentase \\
\hline \multirow{2}{*}{$\begin{array}{l}\text { Jenis } \\
\text { Kelamin }\end{array}$} & Laki-laki & 103 & $64,4 \%$ \\
\hline & Perempuan & 57 & $35,6 \%$ \\
\hline \multicolumn{2}{|c|}{ Total } & 160 & $100 \%$ \\
\hline \multirow[t]{3}{*}{ Umur } & 18-39 Tahun & 125 & $78,1 \%$ \\
\hline & 40-59 Tahun & 26 & $16,3 \%$ \\
\hline & $>50$ Tahun & 9 & $5,6 \%$ \\
\hline \multicolumn{2}{|c|}{ Total } & 160 & $100 \%$ \\
\hline \multirow[t]{6}{*}{ Pendidikan } & Tidak & 2 & $1,3 \%$ \\
\hline & Sekolah & & \\
\hline & SD & 20 & $12,5 \%$ \\
\hline & SMP & 31 & $19,4 \%$ \\
\hline & SMA & 73 & $45,6 \%$ \\
\hline & $\begin{array}{c}\text { Perguruan } \\
\text { Tinggi }\end{array}$ & 34 & $21,3 \%$ \\
\hline \multicolumn{2}{|r|}{ Total } & 160 & $100 \%$ \\
\hline \multirow[t]{5}{*}{ Transmisi } & $\begin{array}{c}\text { Heteroseksual } \\
\text { (Lebih dari } \\
1 \text { pasangan) }\end{array}$ & 87 & $54,4 \%$ \\
\hline & Homoseksual & 53 & $33,1 \%$ \\
\hline & Biseksual & 1 & $0,6 \%$ \\
\hline & Perinatal & 2 & $1,3 \%$ \\
\hline & Transfusi & 1 & $0,6 \%$ \\
\hline
\end{tabular}

\begin{tabular}{cccc}
\hline Karakteristik & $\begin{array}{c}\text { Frekuensi } \\
(\mathrm{N})\end{array}$ & $\begin{array}{c}\text { Presentase } \\
(\%)\end{array}$ \\
\hline \multicolumn{6}{c}{ Darah } & & \\
& Napza Suntik & 11 & $6,9 \%$ \\
& Lainnya & 5 & $3,1 \%$ \\
\hline \multicolumn{2}{c}{ Total } & 160 & $100 \%$ \\
\hline Kelompok & $<50$ & 67 & $41,9 \%$ \\
$\mathrm{CD} 4$ & $50-199$ & 54 & $33,8 \%$ \\
$\left(\mathrm{sel} / \mathrm{mm}^{2}\right)$ & $200-394$ & 19 & $11,9 \%$ \\
& $>350$ & 20 & $12,5 \%$ \\
\hline \multicolumn{2}{c}{ Total } & 160 & $100 \%$ \\
\hline
\end{tabular}

\section{Berdasarkan Tabel 1, karakteristik} subjek penelitian diketahui tinggi-nya prevalensi kasus HIV/AIDS pada laki-laki lebih dikarenakan oleh perilaku seksual berisiko yang lebih rentan dilakukan lakilaki dibandingkan perempuan ${ }^{6}$. Hal ini sesuai dengan penelitian yang dilakukan Saktina,dkk di Rumah Sakit Umum Pusat Sanglah Denpasar, Bali terhadap 179 pasien HIV/AIDS yang menyatakan bahwa jumlah penderita laki-laki $(67,6 \%)$ lebih banyak dibandingkan perempuan $(32,4 \%)$. Dengan demikian kedua penelitian ini mendukung laporan Kementrian Kesehatan Republik Indonesia triwulan IV tahun 2016 bahwa laki-laki yang terinfeksi HIV/AIDS lebih banyak yaitu $67,9 \%$ sedangkan perempuan hanya $31,5 \% .^{7}$

Seiring dengan perkembangan HIV dan AIDS, kelompok tertentu ditemukan lebih rentan memiliki perilaku seksual berisiko terhadap HIV dan AIDS. Kelompok umur remaja merupakan masa krisis dimana pemahaman terhadap perilaku masih belum cukup matang. Walaupun kelompok umur remaja memiliki kemampuan kognitif untuk menentukan perilaku yang sehat, pada prakteknya remaja sering terdorong oleh kekuatan lain yang membuat mereka tidak berperilaku secara sehat. Hal ini sejalan dengan data Ditjen PP dan PL kemenkes $\mathrm{RI}^{8}$, orang yang terinfeksi HIV dan AIDS direntang umur produktif. kejadian kasus AIDS yang dilaporkan sejak 1987 sampai 2016 triwulan 2 terbanyak pada kelompok usia 20-29 tahun sebanyak 31,4\%, diikuti kelompok usia 30-39 tahun sebanyak 30,3\% dan 40-49 tahun sebanyak $12,6 \%$. Hasil penelitian yang dilakukan sejalan dengan Shen,2012 menunjukan hasil yang 
paling banyak adalah umur 18-39 tahun sebanyak $1082(55,5 \%)$ yang dilakukan di China. ${ }^{9}$

Dalam bidang kesehatan misalnya seseorang yang memiliki tingkat pendidikan lebih tinggi diharapkan mempunyai kemampuan menerima informasi kesehatan. Dengan demikian diharapkan memiliki pengetahuan yang baik dan berperilaku aman sehingga terhindar dari infeksi HIV. Hasil penelitian sejalan dengan yang dilakukan di Kota Pekanbaru Hasil penelitian menjelaskan bahwa tingkat pendidikan responden mayoritas tamatan SMA sebanyak 57 orang $(67.9 \%) .{ }^{9}$

Didapatkan dari total 160 sampel transmisi tertinggi yaitu heteroseksual sebanyak 87 responden $(54,4 \%)$ dan homoseksual yaitu sebanyak 53 responden $(33,1 \%)$. Sesuai dengan teori yang didapatkan bahwa, pasangan homoseksual ternyata memiliki faktor risiko perilaku seksual lebih tinggi daripada pasangan heteroseksual. Hal ini tampak dari kecenderungannya untuk memiliki lebih banyak partner seks dan melakukan seks anal. Perilaku pemakaian kondom, terutama pada saat melakukan hubungan seksual berisiko, pada kedua kelompok tidak berbeda, meskipun secara persentase lebih tinggi pada pasangan heteroseksual.

Berdasarkan kelompok jumlah CD4 HIV di RSUD Dr. H. Abdul Moeloek Provinsi Lampung tahun 2018. Didapatkan dari total 160 sampel jumlah CD4 tertinggi yaitu $<50$ sebanyak 67 responden (41,9\%) dan jumlah CD4 terendah yaitu 200 - 349 sebanyak 19 responden (11,9\%). Hal ini sejalan dengan hasil penelitian yang dilakukan oleh (Shen,2013) di China didapatkan jumlah CD4 $<50$ sebanyak 796 responden (40,9\%) dan jumlah CD4 50-199 sebanyak 611 responden $(31,4 \%)$.

Tabel 2. Distribusi Frekuensi Jumlah CD4 pada Pasien yang diberi Isoniazid sebagai Pencegahan TB dan Ko-Infeksi TB pada Pasien HIV/AIDS

\begin{tabular}{ccc}
\hline Parameter & $\begin{array}{c}\text { Rerata } \pm \\
\text { SB/Median }\end{array}$ & Terendah \\
\hline $\begin{array}{c}\text { Jumlah CD4 (sel/mm3) } \\
\text { pasien yang diberi } \\
\text { isoniazid }\end{array}$ & $\begin{array}{c}227,25 \\
(135,50)\end{array}$ & 3 \\
\hline
\end{tabular}

\begin{tabular}{ccc}
\hline Parameter & $\begin{array}{c}\text { Rerata } \pm \\
\text { SB/Median }\end{array}$ & Terendah \\
\hline $\begin{array}{c}\text { Jumlah CD4 (sel/mm3) } \\
\text { pasien ko-infeksi TB }\end{array}$ & $67,01(42,00)$ & 1 \\
$\begin{array}{c}\text { Jumlah CD4 (sel/mm3) } \\
\text { pasien yang diberi } \\
\text { isoniazid }\end{array}$ & $\begin{array}{c}227,25 \\
(135,50)\end{array}$ & 3 \\
\hline
\end{tabular}

Berdasarkan Tabel 2., distribusi frekuensi jumlah CD4 pada pasien yang diberi isoniazid sebagai pencegahan $\mathrm{TB}$ dan ko infeksi TB pada pasien HIV/AIDS di RSUD DR. H. Abdul Moeloek Provinsi Lampung Tahun 2018. Didapatkan rerata jumlah CD4 yang diberi isoniazid yaitu $227,25 \mathrm{sel} / \mathrm{mm} 3$ dengan nilai tengah $135,50 \mathrm{sel} / \mathrm{mm} 3$, nilai minimum $3 \mathrm{sel} / \mathrm{mm} 3$, dan nilai maksimum yaitu $2020 \mathrm{sel} / \mathrm{mm} 3$. Sedangkan untuk rerata jumlah CD4 pasien ko - infeksi TB yaitu 67,01 $\mathrm{sel} / \mathrm{mm} 3$ dengan nilai tengah $42,00 \mathrm{sel} / \mathrm{mm} 3$, nilai minumum $1 \mathrm{sel} / \mathrm{mm} 3$, dan nilai maksimum $321 \mathrm{sel} / \mathrm{mm}$

Tabel 3. Hasil analisis uji Mann-Whitney Korelasi Jumlah CD4 pada pasien yang diberi isoniazid sebagai pencegahan TB dan KoInfeksi TB pada Pasien HIV/AIDS

\begin{tabular}{ll}
\hline Test Statistics $^{\mathrm{a}}$ & CD4 \\
\hline Mann-Whitnev U & 1917.500 \\
Wilcoxon W & 5157.500 \\
Z & -4.377 \\
Asymp. Sig. (2-tailed) & .000 \\
a. Grouping Variable: Pasien_HIV \\
\hline
\end{tabular}

Berdasarkan Tabel 3., hasil uji Mann Whitney diatas dapat dilihat bahwa nilai Asymp. Sig. (2-tailed) adalah 0,000. Setengah dari nilai signifikansi ini $1 / 2(0,000)<0,05$. Maka dapat disimpulkan bahwa menolak $\mathrm{HO}$ dan $\mathrm{Ha}$ diterima yang mengandung pengertian bahwa ada perbedaan yang signifikan jumlah CD4 pada pasien yang diberi isoniazid sebagai pencegahan TB dengan pasien Ko - Infeksi TB. 
Tabel 4. Uji Chi - Square Korelasi Jumlah CD4 pada pasien yang diberi isoniazid sebagai pencegahan TB dan Ko - Infeksi TB pada Pasien HIV/AIDS

\begin{tabular}{|c|c|c|c|c|c|c|c|}
\hline \multirow{2}{*}{$\begin{array}{l}\text { Sel T CD4 } \\
\left(\mathrm{sel} / \mathrm{mm}^{3}\right)\end{array}$} & \multicolumn{2}{|c|}{ Pasien HIV/AIDS } & \multirow{2}{*}{ Total } & \multirow{2}{*}{$\begin{array}{l}\text { Nilai } \\
P\end{array}$} & \multirow{2}{*}{ OR } & \multicolumn{2}{|c|}{$\begin{array}{c}95 \% \text { Confidence } \\
\text { Interval }\end{array}$} \\
\hline & $\begin{array}{l}\text { Diberi } \\
\text { INH }\end{array}$ & $\begin{array}{c}\text { Ko-infeksi } \\
\text { TB } \\
\end{array}$ & & & & Lower & Upper \\
\hline$<200$ & $\begin{array}{c}47 \\
(58,8 \%)\end{array}$ & $\begin{array}{c}74 \\
(92,5 \%)\end{array}$ & $\begin{array}{c}121 \\
(75,6 \%)\end{array}$ & & & & \\
\hline$\geq 200$ & $\begin{array}{c}33 \\
(41,3 \%)\end{array}$ & $\begin{array}{c}6 \\
(7,5 \%)\end{array}$ & $\begin{array}{c}39 \\
(24,4 \%)\end{array}$ & 0,00 & 0,115 & 0,045 & 0,297 \\
\hline Total & $\begin{array}{c}80 \\
(100 \%)\end{array}$ & $\begin{array}{c}80 \\
(100 \%)\end{array}$ & $\begin{array}{c}160 \\
(100 \%)\end{array}$ & & & & \\
\hline
\end{tabular}

Berdasarkan Tabel 4, hubungan Jumlah CD4 pada pasien yang diberi isoniazid sebagai pencegahan TB dan Ko - Infeksi TB pada Pasien HIV/AIDS di RSUD DR. H. Abdul Moeloek Provinsi Lampung Tahun 2018. Didapatkan dari total 160 responden pasien HIV/AIDS. Jumlah CD4 $<200 \mathrm{sel} / \mathrm{mm} 3$ yang dimiliki oleh pasien yang diberi isoniazid sebagai pencegahan TB sebanyak $47(58,8 \%)$ responden, dan yang dimiliki oleh pasien dengan ko - infeksi TB dengan responden 74(92,5\%). Sedangkan jumlah CD4 >200 sel/mm3 yang dimiliki oleh pasien yang diberi isoniazid sebagai pencegahan TB sebanyak 33(41,3\%) responden, dan yang dimiliki oleh pasien dengan ko - infeksi TB dengan responden 6(7,5\%). Setelah dilakukan analisis uji Chi Square dengan tingkat kesalahan 5\% menggunakan SPSS 18 didapatkan nilai $\mathrm{p}=0,00$ dimana nilai $\mathrm{p}<0,05$ menunjukan bahwa Ha diterima, artinya bahwa adanya hubungan jumlah CD4 pada pasien yang diberin isoniazid sebagai pencegahan TB dan ko - infeksi TB. Dengan nilai OR sebesar 0,115 yang berarti orang dengan HIV/AIDS yang memiliki kadar CD4 $<200 \quad$ sel/mm3 lebih beresiko terkena TB daripada orang dengan HIV/AIDS yang mendapat isoniazid sebagai pencegahan TB terlebih dahulu.

CD4 adalah parameter terbaik untuk mengukur imunodefisiensi. Jika digunakan bersamaan dengan penilaian klinis, CD4 dapat menjadi petunjuk dini progresivitas penyakit karena jumlah CD4 menurun lebih dahulu dibandingkan kondisi klinis. ${ }^{10}$ Pengaruh antara jumlah CD4 awal dengan kenaikan didasari oleh kemampuan tubuh untuk memperbaiki sistem imun. Apabila jumlah CD4 awal yang dimiliki pasien lebih rendah maka kemampuan untuk memperbaiki juga akan lebih sulit. Maka, semakin tinggi CD4 awal sebelum terapi maka semakin sedikit risiko mengalami penurunan CD4 ${ }^{11}$

Jumlah CD4 $\quad<200 \quad$ sel/mm3 yang dimiliki oleh pasien yang diberi isoniazid sebagai pencegahan TB sebanyak $47(58,8 \%)$ responden, dan yang dimiliki oleh pasien dengan ko-infeksi TB dengan responden $74(92,5 \%)$. Sedangkan jumlah CD4 $>200 \mathrm{sel} / \mathrm{mm} 3$ yang dimiliki oleh pasien yang diberi isoniazid sebagai pencegahan TB sebanyak 33(41,3\%) responden, dan yang dimiliki oleh pasien dengan ko-infeksi TB dengan responden 6(7,5\%). Setelah dilakukan analisis uji Chi Square dengan tingkat kesalahan 5\% menggunakan SPSS 18 didapatkan nilai $\mathrm{p}=0,00$ dimana nilai $\mathrm{p}<0,05$ menunjukan bahwa Ha diterima, artinya bahwa adanya hubungan jumlah CD4 pada pasien yang diberi isoniazid sebagai pencegahan TB dan koinfeksi TB.

Penelitian ini juga sejalan dengan penelitian di Afrika Selatan bahwa pasien HIV/AIDS yang mendapatkan isoniazid sebagai pencegahan TB selama 4 bulan mempunyai jumlah CD4 >340 sel/mm3 (Page ship dkk, 2018). Dalam penelitian Chaisson, dkk membandingkan tingkat kejadian $\mathrm{TB}$ dan kematian TB dengan jumlah CD4 dan pemberian isoniazid sebagai pencegahan TB. Penderita HIV/AIDS dengan jumlah CD4 350 $\mathrm{sel} / \mathrm{mm} 3$ atau kurang namun tidak menerima isoniazid sebagai pencegahan TB didapatkan tingkat kejadian TB atau Ko-infeksi TB 179 orang/tahun dan angka kematian 57 orang/tahun sedangkan pasien yang dengan CD4 >350 
$\mathrm{sel} / \mathrm{mm} 3$ tidak menerima isoniazid didapatkan kejadian TB dan kematian TB 57 orang/tahun. Diketahui tingginya kejadian TB diantara semua pasien yang tidak menerima isoniazid sebagai pencegahan $\mathrm{TB}$, termasuk mereka dengan jumlah CD4 $>350 \mathrm{sel} / \mathrm{mm} 3$ terapi pencegahan TB harus disediakan untuk semua orang yang hidup dengan HIV terlepas dari jumlah CD4 nya. Dalam model multivariat Cox proporsional hazard membandingkan pasien yang diberi isoniazid sebagai pencegahan TB dengan tanpa diberi isoniazid, didapatkan hasil bahwa pasien yang diberi isoniazid didapatkan jumlah CD4 $>500 \mathrm{sel} / \mathrm{mm} 3$, sedangkan yang tidak diberi isoniazid TST ( Tuberculin Skin Test) positif dan didapatkan jumlah CD4 $<200 \mathrm{sel} / \mathrm{mm} 3 .{ }^{12}$

\section{SIMPULAN DAN SARAN}

Rerata jumlah CD4 yang diberi isoniazid yaitu $227,25 \mathrm{sel} / \mathrm{mm} 3$ dengan nilai tengah $135,50 \mathrm{sel} / \mathrm{mm} 3$, nilai minimum 3 $\mathrm{sel} / \mathrm{mm} 3$, dan nilai maksimum yaitu 2020 $\mathrm{sel} / \mathrm{mm} 3$. Sedangkan untuk rerata jumlah CD4 pasien ko - infeksi TB yaitu $67,01 \mathrm{sel} / \mathrm{mm} 3$ dengan nilai tengah $42,00 \mathrm{sel} / \mathrm{mm} 3$, nilai minumum $1 \mathrm{gr} / \mathrm{dl}$, dan nilai maksimum 321 $\mathrm{sel} / \mathrm{mm} 3$. Terdapat perbandingan signifikan jumlah CD4 pada pasien yang diberi isoniazid sebagai pencegahan TB dengan pasien Ko Infeksi TB dilihat dari hasil uji Mann - Whitney diatas dapat dilihat bahwa nilai Asymp. Sig. (2tailed) adalah 0,000 . Setengah dari nilai signifikansi ini $1 / 2(0,000)<0,05$. Maka dapat disimpulkan bahwa menolak $\mathrm{H} 0$ dan $\mathrm{Ha}$ diterima yang mengandung pengertian bahwa ada perbedaan yang signifikan Terdapat korelasi antara Jumlah CD4 pada pasien yang diberi isoniazid sebagai pencegahan TB dan Ko Infeksi TB yang bermakna dengan nilai $\mathrm{p}=$ 0,00, menunjukan kekuatan korelasi hubungan sedang dengan arah korelasi positif.

Hasil penelitian ini dapat digunakan sebagai referensi bagi peneliti selanjutnya sebagai dasar teori untuk penelitian tentang pengaruh pemberian Isoniazid terhadap jumlah CD4 pada pasien HIV/AIDS.

\section{UCAPAN TERIMA KASIH}

Terimakasih kami sampaikan kepada

RSUD Dr. H. Abdul Moeloek Provinsi Lampung.

\section{REFERENSI}

1. Pusat Data Dan Informasi Kementerian Kesehatan Republik Indonesia, Jakarta Selatan: Kementerian Kesehatan Republik Indonesia; 2019 [online] Available at: <https://pusdatin.kemkes.go.id> [Accessed 23 March 2020].

2. Marsh K, Eaton J, Mahy M, Sabin K, Autenrieth C, Wanyeki I, et al. Global, regional and countrylevel 90-90-90 estimates for 2018: assessing progress towards the 2020 target. AIDS. 2019; 33 Suppl 3(Suppl 3): S213-S226.

3. Moural TW, White DS, Choy CJ, Kang C, Berkman CE. Crystal Structure of phosphoserine BlaC from Mycobacterium tuberculosis inactivated by bis (benzoyl) phosphate. Int J Mol Sci. 2019; 20 (13): 3247.

4. Kementerian Kesehatan Republik Indonesia. Petunjuk teknis tata laksana klinis ko-infeksi TBHIV. Jakarta: Kementerian Kesehatan RI; 2012.

5. Grant AD, Charalambous S, Fielding KL, Day $\mathrm{JH}$, Corbett EL, Chaisson RE, et al. Effect of routine isoniazid preventive therapy on tuberculosis incidence among HIV-infected men in South Africa: a novel randomized incremental recruitment study. Jama. 2005; 293 (22): 2719-25.

6. Kambu Y, Waluyo A, Kuntarti K. Umur orang dengan HIV AIDS (ODHA) berhubungan dengan tindakan pencegahan penularan HIV. Jurnal Keperawatan Indonesia. 2016; 19 (3): 200-7.

7. Saktina PU, Satriyasa BK. Karakteristik penderita AIDS dan infeksi oportunistik di rumah sakit umum pusat Sanglah Denpasar periode Juli 2013 sampai Juni 2014. E-Jurnal Medika Udayana. 2017; 6 (3).

8. Pusat Data Dan Informasi, Jakarta Selatan: Kementerian Kesehatan Republik Indonesia; 2019 [online] Available at: <https://pusdatin.kemkes.go.id/article/view/17020 100001/situasi-penyakit-hiv-aids-diindonesia.html> [Accessed 23 March 2020].

9. Shen Y, Wang Z, Lu H, Wang J, Chen J, Liu L, et al. Prevalence of anemia among adults with newly diagnosed HIV/AIDS in China. PLoS One. 2013; 8 (9).

10. Dokumen Kebijakan, Yogyakarta: Kebijakan AIDS Indonesia; 2018 [online] Available at: <https://www.kebijakanaidsindonesia.net/id/doku men-kebijakan> [Accessed 23 March 2020]. 
11. Yogani I, Karyadi TH, Uyainah A, Koesnoe S. Faktor-faktor yang Berhubungan dengan kenaikan CD4 pada pasien HIV yang mendapat highly active antiretroviral therapy dalam 6 bulan pertama. Jurnal Penyakit Dalam Indonesia. 2015; 2 (4): 217-22.

12. Golub JE, Cohn S, Saraceni V, Cavalcante SC, Pacheco AG, Moulton LH, Durovni B, Chaisson RE. Long-term protection from isoniazid preventive therapy for tuberculosis in HIVinfected patients in a medium-burden tuberculosis setting: the TB/HIV in Rio (THRio) study. Clinical Infectious Diseases. 2015; 60 (4): 63945. 